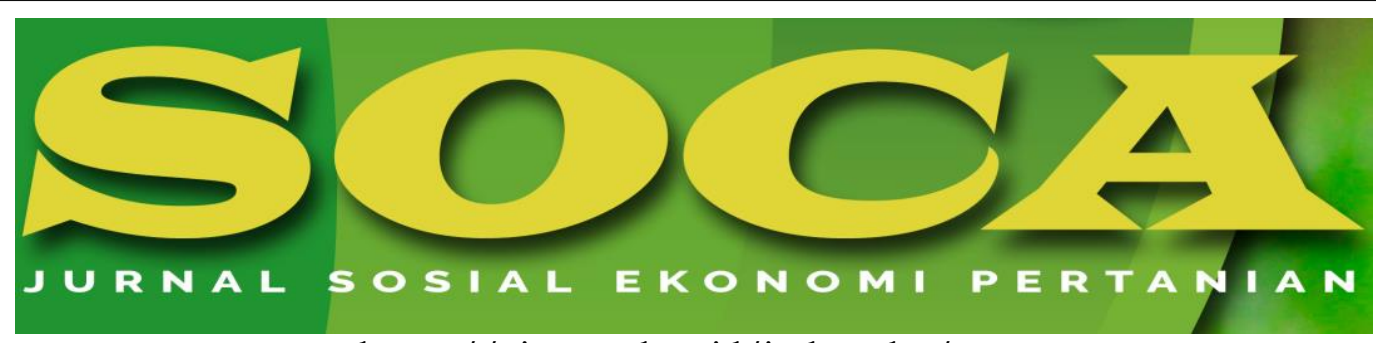

https://ojs.unud.ac.id/index.php/soca

\title{
The Connection Of Entrepreneurship Characteristics And Business Performance Of Arabika Coffee Farmers
}

\author{
Elvin Desi Martauli \\ Agribusiness Department, Quality Berastagi University \\ Email: elvindesi@ymail.com \\ Mobile: 085266587181
}

Submitted : 30 January ; Revised : 9 February 2020 ; Accepted: 14 February 2020

\section{Keywords: \\ characteristics; entrepreneursh ip; business performance; Arabica coffee farmers..}

\begin{abstract}
Entrepreneurship is a very important element in development, including in agriculture. One of the agriculture subjects that must have entrepreneurship characteristics to be able to encourage the improvement of farm performance is the farmer. The farmers in Tigapanah Sub-district, Karo District are farmers who are able to survive in performing coffee farming activities within various risks. The aim of this study was to analyze the cennection between entrepreneurship characteristics of Arabica coffee farmers in Tigapanah District to the farming performance. The method of sampling respondents was determined by the simple random sampling which involved 850 Arabica coffee farmers. The farmers in this study were 5\% of the total respondents, which approximately 43 people. Based on the correlation analysis of Spearman Rank, on SPSS 20 was used to analyze the relationship between entrepreneurship characteristics to the farming performance. Based on the correlation analysis Spearman's Rank, the results obtained that there was a positive and significant correlation between the characteristics of entrepreneurship with the performance of Arabica coffee farming. Positive and significant correlations were described by risk-taking, self-confident, task-and-outcome-oriented variables, leadership, future oriented and hard work towards the performance of Arabica coffee farming, which are market share, sales quantity, and income.
\end{abstract}

How to Cite (APA 6 ${ }^{\text {th }}$ Style):

Martauli, E. D. (2020). The Connection Of Entrepreneurship Characteristics And Business Performance Of Arabika Coffee Farmers. SOCA: Jurnal Sosial Ekonomi Pertanian, 14(2), 339-350.

https://doi.org/https://doi.org/ 10.24843/SOCA.2020.v14.i02.p13 


\section{INTRODUCTION}

Entrepreneurship is one of the most important elements in development which includes economic growth and community welfare. The community entrepreneurial activities are able to increase the economic growth in the region. The wider coverage is that the country can also develop with the support of entrepreneurial activities (Basrowi, 2017). According to Basrowi, 2017, that entrepreneurship has several benefits such as the opportunity to be able to make a change, the desire to reach self- potential and be active in society. The importance of entrepreneurship development is in various fields including in agriculture.

According to Pambudy et al. (2017) agroindustry is the oldest business enterprise which included in the small business industry group. The small business industry groups are services, retail, wholesaling, agroindustry and manufacture. The character of a small business in general is that the independently management, the stock comes from the owner and limited business operational (locally). According to (Purwaningsih and Damar, 2015) the quality of human resources, mastering in technology, management, organizational structure, stock, network systems are internal factors for business success.

Coffee (Coffee $\mathrm{Sp}$ ) is one of the commodities of plantation products with half contribution to the total export of tropical commodities which has an important role of the Indonesian economy activities, thus give a big contribution to the country's foreign exchange. Indonesia is included in the fourth world coffee producer after Vietnam, Brazil and Colombia. The total coffee production in 2017 was 523.83 thousand tons of coffee per year with total household coffee consumption experiencing a significant increase of $10.54 \%$ (Asih, 2009).

Based on the data from Indonesian Plantation Statistics Coffee Commodities 2013-2017 Directorate General of the Ministry of Plantation and Agriculture, the contribution of the plantation sub sector to the national economy is increasing from year to year. This condition is certainly directly proportional to the productivity of Arabica coffee. The overall national scope of coffee commodities from 2013 to 2017 showed insignificant changes. The coffee planting area that produces nationwide has increased. The coffee productivity increased within the increasing planting area. The decrease in coffee productivity occurred in 2013 and 2017. In 2013, coffee productivity was $725 \mathrm{~kg} /$ ha and in 2017 it was $722 \mathrm{~kg} /$ ha. Based on this amount, the decrease in productivity occurred by 0.41 percent.

Entrepreneurship characteristics are the characters in a person which is encouraging entrepreneurship activities. In Jumaedi research (2012) explained that entrepreneurship is an activity consisting of creating goods or services with continuous processes between the production processes, the supporting processes which are the process of human resources, planning processes, marketing processes and others. Based on Jumaedi (2012) the characters of entrepreneurship (selfconfidence, risk taking and leadership) had a positive effect on the business success. In the research of Isa et al., 2011, stated that entrepreneurs are innovative, risk takers, anticipatory, initiative and profit oriented.

This entrepreneurship characteristic has the most influence to the business success (Santoso, 2014). Based on the result of Syawaludin et al. research (2015), entrepreneurship characteristics which include leadership, task and outcome oriented, self-confidence, risk taking and future oriented have a good impact on business growth. Endang (2012) explained that an entrepreneur is someone who is 
always required to face risks or opportunities that arise with creative and innovative actions.

Business performance as a business development has several influence indicators. Sari et al. (2016) in her study stated that business performance is a measure of the business run by the successful entrepreneurs. In Wahyuningsih's research (2015) stated that the majority of business success, especially in small businesses, is determined by the entrepreneurship factors. The main factor is the entrepreneur personality, ability to applying technology as a supporting factor. Business performance required entrepreneurship characteristics such as innovation so that it affected the development of a business.

Tigapanah Sub-district is one of the Arabica coffee producing areas in Karo Regency, North Sumatra. Coffee has become one of the mainstay commodities of the community with farmer background and other professions that moved to plant Arabica coffee. The economy of the community has increased when the price of coffee especially Arabica coffee has increased on the market. Fertile soil and suitable climate supported this commodity to grow with significant productivity. The agricultural land in the Tigapanah Sub-district was then dominated by the Arabica coffee. The development of Arabica coffee was very fast because the price is good for Arabica coffee farmers-side.

Farmers in Tigapanah sub-district who were originally migrant farmers in the Arabica coffee commodity farming have had several impacts. The lack of practical experience of farmers has resulted in the maintenance and practical management of this farming being not optimal. The data from the Agricultural Counseling Institution of Tigapanah District (2018) showed that the number of farmers from 2012 to 2017 showed that the number of surviving farmers has not decreased despite the price and risk management of Arabica coffee. The coffee prices that have fluctuated can be known from conditions in the study area. The farmers selled Arabica coffee in the form of dried beans or cherry coffee at the offered price which was around Rp. 25,000 per kg.

The rise of several factors that influenced Arabica coffee farming activities make farmers still be able to produce Arabica coffee. In 2011 to 2015, Arabica coffee production has increased, although not significantly, and in 2014 Arabica coffee has decreased from the previous year. Arabica coffee production was then able to increase the following year with a significant number compared to the previous year. The increase in Arabica coffee production then occurred in the following year, 2016. Farmers in the area still survived cultivating Arabica coffee in the midst of price fluctuations and inadequate practical management of farming. This condition showed the character of farmers who are able to deal with changes and risks in farming. The study aimed to determine the entrepreneurship characteristics possessed by farmers, analyze the performance of farming and analyze the connection between farmer entrepreneurship characteristics to the performance of Arabica coffee farming in Tigapanah Sub-district.

\section{RESEARCH METHODS}

The research was conducted from May to July 2019 in the Kutambelin village, Kacinambun village, Suka village, Sukamaju village, Tigapanah village that located in Tigapanah Sub-district, Karo Regency. The selection of research sites was purposive done, because this place is the location of the Arabica coffee plantation. 
The method in this research is to take the sample using Simple Random Sampling which is a sampling of members of the population who are pickled with no regard to the level in the population used (Sugiyono, 2017). The research population means the Arabica coffee farmers in the Tigapanah Sub-district, Karo Regency, North Sumatra. The research area sample was taken from 5 villages from 20 villages which are Kutambelin Village, Kacinambun Village, Suka Village, Sukamaju Village, Tigapanah Village. Respondents in this research were farmers who worked on Arabica coffee farming. The total respondents in this research are 850 people, so the sample taken was $5 \%$ of the respondents, which are 43 people.

In this research, the type of data used is secondary data and primary data where primary data is done by interviewing, giving questionnaires and documentation or questions to the sample of respondents. Secondary data comes from related institutions, research, literature, books or the internet.

The data obtained then processed using Microsoft Excel computer software and SPSS 20 for Windows. Data analysis was performed by processing data qualitatively and quantitatively. The aimed of data analysis is to answer every question contained in the research objectives. The aimed of descriptive statistical analysis was to describe the entrepreneurship characteristics and business performance of Arabica coffee farmers. Descriptive method was used in processing qualitative data to determine the characteristics that dominate Arabica coffee farmers. Qualitative data was then presented in the form of quantitative data using Microsoft Excel.

\section{Spearman's Rank Correlation Analysis}

This analysis was used to see the correlation between variables based on rank. In this research, this analysis was used to determine the connection between entrepreneurship characteristics which used by Arabica coffee farmers and the performance of farmers in Tigapanah Sub-district. Correlation of variables can be categorized as very weak, weak, medium, strong and very strong. Correlation analysis was using SPSS 20 for windows. The correlation coefficient result was the measurement to the two variables, $\mathrm{X}$ and $\mathrm{Y}$. Variable $\mathrm{X}$ is the entrepreneurship characteristic and $\mathrm{Y}$ variable is the business performance. The requirements for the measurements were the correlation coefficient value must be greater than the value of $r$ table. In the SPSS output, it will be seen that the correlation coefficient value that significantly related will have an asterisk. Furthermore, the two variables are stated to be significantly related by looking at the value of rs output SPPS. The value of rs showed how strong the correlation between the two variables. There are five categories used to see the value of rs, they are:

1. If $0<|\mathrm{rs}|<0.2$, then both variables are categorized as very weak correlated

2. If $0.2 \leq|\mathrm{rs}|<0.4$, then both variables are categorized as weak correlated

3. If $0.4 \leq|\mathrm{rs}|<0.6$, then both variables are categorized as medium correlated

4. If $0.6 \leq|\mathrm{rs}|<0.8$, then both variables are categorized as strong correlated

5. If $0.8 \leq|\mathrm{rs}|<1$, then both variables are categorized as very strong correlated 


\section{RESULTS AND DISCUSSION}

\section{Characteristics of Arabica coffee farmers in Tigapanah Sub-District}

Most of Arabica coffee farmers in Tigapanah sub-district were in the productive age range, where almost 58 percent of the respondents were in the range of 40 - 52 years old, and followed by 30 percent respondents in the range of $25-40$ years old. While 12 percent of them were over 57 years old (picture 1), the productive age of this coffee farming was concluded that coffee farming is quite attractive to be used as the livelihood. Besides that, it was also supported by the characteristics of the Karo Regency as an agricultural area (Martauli and Siahaan, 2019). Furthermore, farmers with a productive age of 20-50 years old may receive innovation. Farmers in productive age still have strong physical strength, so that it was possible to be optimal in agricultural activities (Asih, 2009).

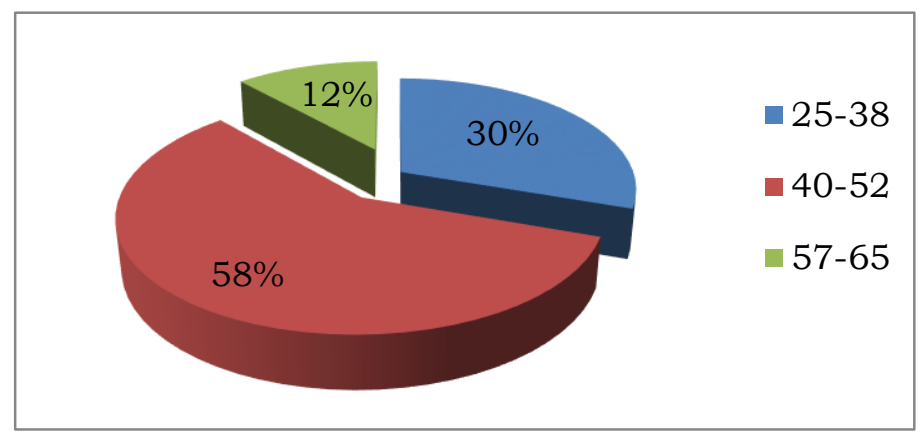

Picture 1. Percentage of coffee farmers by age

Education is one of the supporting factors that influence the success of the business. This means that good education will provide additional new knowledge for farmers in doing the agricultural entrepreneurship activities. In picture 2, Arabica coffee farmers in Tigapanah sub-district have a quite diverse level of education, from elementary school to bachelor level. Farmers who just graduated from Elementary school was 5 percent, Junior High schools 26 percent, High schools 67 percent, Bachelor 2 percent of the total. Most farmers have graduated from high school.

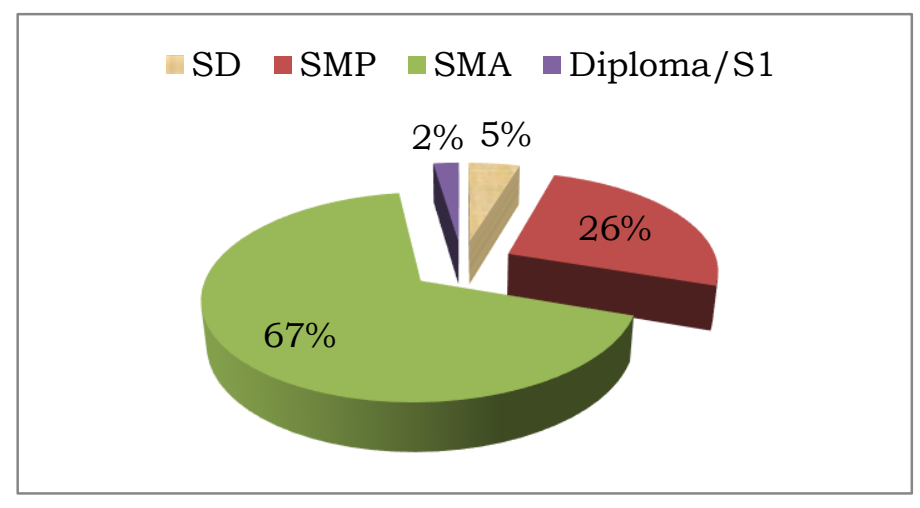

Picture 2. Percentage of coffee farmers by school graduates

The land used for farming is the land owned by the farmers themselves, not rented land or profit sharing. The coffee fields that used previously were used to oranges planting.

The experience of the Arabica coffee farmers was mostly average between 510 years, which is $73 \%$ (picture 3), this showed that these farmers were quite 
experienced in doing Arabica coffee entrepreneur business, conducting from the cultivation process to the marketing process. So it was concluded that the opportunity for farmers to be able to develop an Arabica coffee business is likely to succeed. Followed by farmers with less than five years of experience, this showed the number of farmers who continue Arabica coffee farming from parents nor husbands, and also new farmers who are interested in Arabica coffee farming.

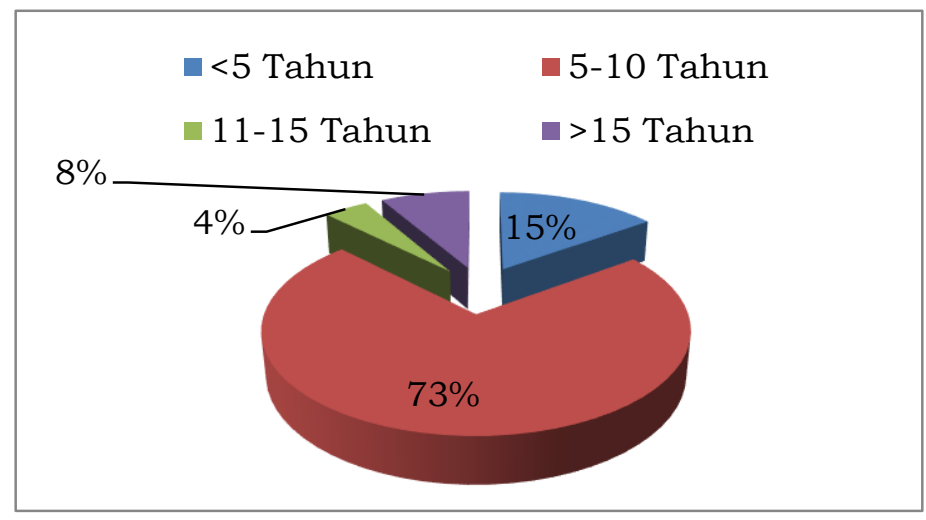

Picture 3. Percentage of coffee farmers by experiences

The land area of Arabica coffee farming mostly has narrow land area, which is in the range of $0.5-1.5$ ha (71\%). This showed that in general Arabica coffee farming is still being cultivated on a small business, which turn out have an effect to the income (picture 4). (Djuwendah, 2019) stated that land functions as a combination of other factors of production (stock, labor and skills) so that it can produced products in the form of plants or livestock. Coffee business land $<0.5 \mathrm{Ha}$ showed that the land area of java preanger coffee farmers is relatively narrow so that the production is limited.

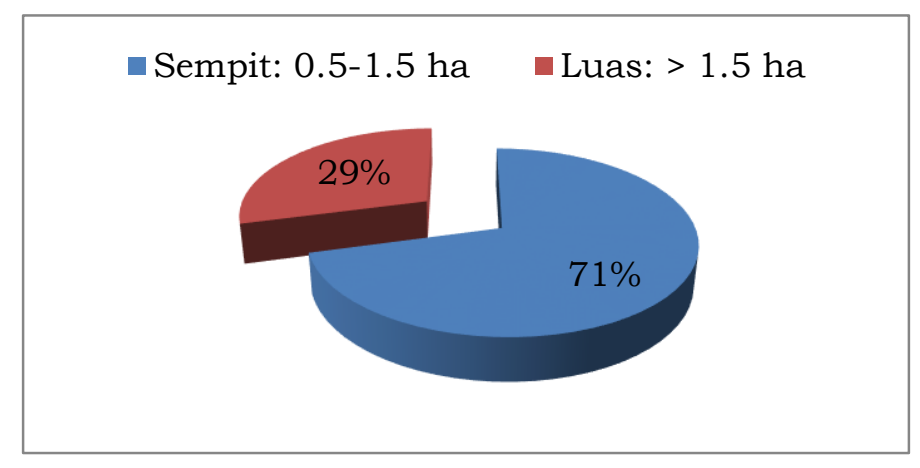

Picture 4. Percentage of coffee farmers by land area

\section{Connection between Entrepreneurship Characteristics and Business Performance}

The arabica coffee farmers in Tigapanah Sub-district have a different character. The strong character in farmers made them able to maintain Arabica coffee to keep producing. To build entrepreneurship characteristics is very important, because entrepreneurship characteristics will determine the success of the business stated in the research (Sari et al, 2016). This research examined several characteristics of entrepreneurship, which are self-confidence, future-oriented, risktaking, hard work, leadership, future oriented and innovative. The previous research done by (Setyawati, 2013) explained that entrepreneurship orientation influenced the 
performance directly. The positive influential relationship can be seen from the entrepreneurship orientation towards competitive supremacy and the uncertainty perception of environmental as the prediction of moderating variables.

Some of these characters were adapted to the conditions of coffee farmers and then connected to the business performance of Arabica coffee farmers. This is done to determine the connection between entrepreneurship characteristics with business performance. The previous research by Jumaedi (2012), about the connection of entrepreneurship characteristics with business performance. Based on the results of the analysis showed that the entrepreneurship characteristics; risk-taking, leadership and self-confidence have a real positive influenced to the success of businesses in Pekalongan. The results of Spearman's Rank correlation analysis of entrepreneurship characteristics with the business performance of Arabica coffee farmers in Tigapanah Sub-district can be seen in Table 1 below.

Table 1. Connection between entrepreneurship characteristics and farmer business performance

\begin{tabular}{|c|c|c|c|c|c|c|}
\hline \multirow{2}{*}{$\begin{array}{l}\text { Entrepreneurship } \\
\text { Characteristics }\end{array}$} & \multicolumn{2}{|c|}{ Sales } & \multicolumn{2}{|c|}{ Income } & \multicolumn{2}{|c|}{ Market share } \\
\hline & Koef. & $\begin{array}{c}\text { P- } \\
\text { value }\end{array}$ & Koef. & $\begin{array}{c}\text { P- } \\
\text { value }\end{array}$ & Koef. & $\begin{array}{c}\text { P- } \\
\text { Value }\end{array}$ \\
\hline Self-Confidence & $0,664^{* *}$ & 0,000 & $0,627^{* *}$ & 0,000 & 0,241 & 0,002 \\
\hline $\begin{array}{l}\text { outcome } \\
\text { Oriented }\end{array}$ & $0,576^{* *}$ & 0,000 & $0,759^{* *}$ & 0,000 & $0,367^{*}$ & 0,020 \\
\hline Risk-taking & $0,675^{* *}$ & 0,000 & $0,635^{* *}$ & 0,000 & 0,225 & 0,001 \\
\hline $\begin{array}{l}\text { Leadership } \\
\text { Hardwork }\end{array}$ & $\begin{array}{l}0,495^{* *} \\
0,880^{* *}\end{array}$ & $\begin{array}{l}0,003 \\
0,000\end{array}$ & $\begin{array}{l}0,682^{* *} \\
0,705^{* *}\end{array}$ & $\begin{array}{l}0,000 \\
0,009\end{array}$ & $\begin{array}{l}0,381^{*} \\
0,226\end{array}$ & $\begin{array}{l}0,015 \\
0,161\end{array}$ \\
\hline Future Oriented & $0,353^{*}$ & 0,024 & $0,607^{* *}$ & 0,000 & $0,362^{*}$ & 0,012 \\
\hline Innovative & $0,360 *$ & 0,023 & $0,561^{* *}$ & 0,000 & $0,328^{*}$ & 0,039 \\
\hline
\end{tabular}

Note $\quad\left(^{*}\right) \quad$ : significantly correlates at $1 \%$ significance level

$\left({ }^{* *}\right) \quad$ : significantly correlates at $5 \%$ significance level

Table 1 showed that self-confidence has a significant connection to the sales volume of Arabica coffee and the income level of the farmers. The results of the Spearman's Rank analysis showed that self-confidence and business performance are connected. That means there was a correlation coefficient of 0.664 which can be categorized as a strong correlation. Whereas, the correlation coefficient value of the self-confidence variable of 0.627 is also included in the strong correlation. Meanwhile, the value of the correlation coefficient between self-confidence with marketing of 0.241 has no correlation. The positive correlation value indicated that the higher sales volume will encourage the farmers' confidence to be even higher. The level of confidence from the good sales results will make farmers stand out and be responsible for the decision to be a coffee farmer. Similarly, the income obtained by farmers is positively correlated with confidence. According to (Sirappa et al, 2017) that the character of an entrepreneur is self-confidence, brave in taking risks, having a leadership skill will have a positive effect on the level of success of the recent business.

The value of the correlation coefficient of task and outcome oriented (Table 1) has a significant connection to sales volume, income, market share. The results of the analysis using the Spearman's Rank between task and outcome oriented with sales volume with a coefficient value of 0.576 , which is in the medium category, 
between task and outcome oriented with income of 0.759 with strong category and task-and outcome-oriented characters and market share of 0.367 including in the weak correlation category. Therefore, it can be concluded that the higher tasks and outcome oriented, the more it will increase the volume of coffee sales, income. Farmers in Tigapanah Sub-district, so that the Arabica coffee planted can continue to produce and provide benefits. The selling price of coffee and the age of coffee trees conditions do not cause farmers to stop in their business. One of the attempts made by farmers to taking care their agricultural land is by providing organic and chemical fertilizers. It is because coffee is one source of income for families to meet their needs. This is in line with the (Dhamayantie and Fauzan, 2017) opinion, that entrepreneurship characteristics such as leadership, task and outcome oriented, confidence, risk taking and future orientated have a good impact on the business development.

Table 1, the risk-taking character has a correlation coefficient value that indicated a significant correlation with three business performances; they are sales volume, income. The analysis using Spearman's Rank showed that there was a connection between risk-taking and business performance of Arabica coffee farmers. The results of Spearman's Rank analysis between risk-taking and sales volume performance resulted in a correlation coefficient of 0.675 included in the strong correlation category. Correlation coefficient value between risk-taking and income of 0.635 is included in the strong correlation category. The correlation coefficient value between risk-taking and market share performance is 0.225 . This amount showed that the risk-taking character is uncorrelated and significant with market share. Therefore, it can be concluded that risk-taking is positively correlated with sales volume which showed that the higher the risk-taking, the higher the sales volume and income. Having the character of being brave to take risks is very important to an entrepreneur, to support the business success. An entrepreneur is going to like businesses that are risky or more challenging. Risk is one of the factors that push an entrepreneur to achieve success of the business. This condition is also seen in Arabica coffee farmers in Tigapanah Sub-district. (Dhamayantie and Fauzan, 2017) explained that an entrepreneur is someone who is always required to face risks or opportunities that arise with creative and innovative actions.

In table 1 , this condition can be used as a reason for farmers in general to agree with statements of risk-taking and having challenges. This is also seen from the ability of farmers to remain able to maintain and even increase sales volume, Arabica coffee income. Arabica coffee farmers have no difficulty in selling Arabica coffee products because they sell to the wholesaler. The ability of Arabica coffee farmers to take risks in the Arabica coffee business depended on several things. The believed in themselves which is an indicator of the self-confidence character becomes one of the factors. Besides that, there are other factors such as the ability to find opportunities, benefits and face any risks that exist realistically. The risk-taking character and having a challenge makes farmers stay to manage, not easily discouraged, trying to minimize risks and like challenges. (Isa et al., 2011) Entrepreneur is someone who is innovative, risk-taking, anticipatory and seeking for profit.

Leadership character (Table 1) has a correlation coefficient value that indicates a significant correlation with four business performances; they are sales volume, market share and income. The analysis using Spearman's Rank showed that there is a connection between leadership character and business performance of Arabica coffee farmers. The results of the Spearman's Rank analysis between leadership and sales volume performance showed a correlation coefficient value of 
0.495 included in the medium correlation category. The value of the correlation coefficient between leadership and income of 0.682 is included in the strong correlation category. The value of the correlation coefficient between leadership and market share performance of 0.381 is included in the category of weak correlation. Based on the results of the obtained data, it can be concluded that leadership is positively correlated with sales volume, which indicates that the higher leadership leads to increased sales volume and income. This character is a character that showed an exemplary and pioneering. This ability supported an entrepreneur to be able to use his influence for the success of a business. The farmers in Tigapanah Sub-district have a leadership character. This character can be seen from the attitude of farmers who help each other to improve welfare by farming. The concrete application of this character is that farmers accept suggestions and criticisms from others to improve their self-quality. In addition, farmers who already have Arabica coffee then voluntarily provide Arabica coffee seeds to other farmers. Other conditions showed that farmers are able to provide solutions for the Arabica coffee management problems faced by other farmers.

The character of hard work has a correlation coefficient value that indicated a significant correlation with three business performances, there are sales volume, income. The Spearman's Rank analysis that has been done showed the results function to see the connection between hard work and the business performance of Arabica coffee farmers. Spearman's Rank analysis results showed the character of hard work with sales volume performance has a correlation coefficient value of 0.880 . This value showed the correlation of hard work with sales performance volume included in the category of very strong correlation. Correlation coefficient value between hard work and profit that is equal to 0.705 included in the category of medium correlation. While the value of the correlation coefficient between hard work and marketing of 0.226 . This value indicated the character of hard work is not significantly correlated with marketing. Based on the results of the obtained data, it can be concluded that hard work is positively correlated with sales volume and income, which indicates that the higher the hard work, the higher the sales volume and income of Arabica coffee. In general, the hard work character is a character owned by Arabica coffee farmers in Tigapanah Sub-district. The Arabica coffee farmers must work hard so that Arabica coffee can still produce. The farmer's hard work is an effort to develop Arabica coffee and improve well-being. This character can be known by the time disciplined routines of farmers to manage Arabica coffee.

Table 1, future oriented characters have correlation coefficient values which indicated a significant correlation with four business performances, they are sales volume, market share and income. The analysis using Spearman's Rank showed that there is a connection between the character of future oriented with the business performance of Arabica coffee farmers. The results of Spearman's Rank analysis between future oriented and sales volume performance resulted in a correlation coefficient value of 0.353 included in the weak correlation category. The value of the correlation coefficient between future oriented with income that is equal to 0.607 included in the category of strong correlation. The value of the correlation coefficient between the future oriented with the performance of the market share of 0.362 included in the weak correlation category. Based on the results of the obtained data, it can be concluded that the future oriented is positively correlated with sales volume, income and market share, which indicated that the higher the future oriented, the higher the volume of Arabica coffee sales.

Future-oriented characters must be owned by an entrepreneur. This character is a character that requires farmers to have a view to the future. The Arabica coffee 
farmers have a goal to develop Arabica coffee. The aim is to produce good quality coffee with increased output. In addition, farmers also have the aim of increasing the land area of Arabica coffee. The efforts made to achieve this goal are still not optimal. Some problems such as maintenance costs and fertilization costs still cannot be overcome in the process of achieving goals. To increase the output and quality of Arabica coffee requires insights and foresight. The Arabica coffee farmers tried to see the condition of the Arabica coffee market. The available market with high demand is an opportunity for farmers to continue to get benefit. The market demand can be met if Arabica coffee can still produce output according to market demand needs. One of the farmers' efforts is to replace Arabica coffee which has begun to enter the unproductive age with new Arabica coffee. This new Arabica coffee tree is expected to be able to produce Arabica coffee with increasing productivity.

Table 1, the innovative character has a correlation coefficient value that indicated a significant correlation with four business performances; they are sales volume, market share and income. The analysis using Spearman's Rank showed the connection between innovative characters and the business performance of Arabica coffee farmers. The results of Spearman's Rank analysis between innovative and sales volume performance resulted in a correlation coefficient value of 0.360 included in the weak correlation category. Correlation coefficient value between innovative with income that is equal to 0.561 included in the medium correlation category. While the value of the correlation coefficient value between innovative and market share performance of 0.328 is included in the category of weak correlation. Innovative characteristics are very important characters to increase the chances of the success of a business including in agriculture. The efforts in innovation will certainly make a business different from other businesses. Based on the calculation results and Spearman's Rank analysis, innovative characters are the characters that have the lowest score and the correlation coefficient is smaller than other entrepreneurial characteristics. Farmers still have the desire to find new things based on the innovative characteristics. Some farmers disagree with the statement regarding the innovative characteristics presented in the questionnaire. This is because some farmers feel unable to do new things because of age. The treatment of Arabica coffee is generally considered to be sufficient to maintain Arabica coffee. According to Vincent and Adel (2016) that to facilitate the maintenance and harvesting process of coffee, the plant height does not exceed $160 \mathrm{~cm}$. In addition, the height of $160 \mathrm{~cm}$ coffee plant is assumed to be more fertile and less risk of being attacked by pests.

\section{CONCLUSION}

Based on the research results that have been outlined in the discussion, it can be concluded that: Most of Arabica coffee farmers in Tigapanah Sub-district were in the productive age range of 40 - 52 years old. The highest percentage of education was high school, 67 percent. The land area of Arabica coffee farming has a narrow area of land, which is in the range of 0.5-1.5 ha by 71 percent which own by the farmer. The average experience farmers were 5-10 years with 73 percent. Entrepreneurship characteristics owned by Arabica coffee farmers in Tigapanah Sub-district are included in the very good category because they have high scores. Task and results oriented are the characteristics with the highest score with a value of 0.576 variable sales volume; a value of 0.759 on the income variable. Innovative is the characteristic of Arabica coffee farmers which have the lowest score. This is appropriate with the conditions on the area that showed Arabica coffee farmers do not use technology in growing Arabica coffee. Entrepreneurship characteristics of 
Arabica coffee farmers consisting of task and outcome oriented, leadership, future oriented and innovative have a significant connection with farmers' business performance, they are sales volume, income and market share. The entrepreneurship characteristics of self-confidence, risk-taking and hard work are significantly correlated with sales volume, income. These two characteristics are not significantly correlated with market share.

\section{RECOMMENDATION}

Farmers need to maintain this character so that they can improve business performance. External factors are supporting that need to be given to farmers such as counseling, access costs and information to develop entrepreneurship characteristics of Arabica coffee farmers. It is necessary to develop an innovative character in farmers, innovative will be able to increase the quantity and quality of Arabica coffee. This certainly has the potential to make farmers not only produce Arabica coffee but be able to process it into processed Arabica coffee products with a higher value. Arabica coffee farmers in Tigapanah Sub-district can be a location for further research, especially those that raise entrepreneurship issues. The development of entrepreneurship of farmers, especially in rural areas or districts, supported the potential for improving farmers' welfare.

\section{REFERENCES}

Asih, Dewi N. (2009). Analisis Karakteristik Dan Tingkat Pendapatan Usahatani Bawang Merah Di Sulawesi Tengah. Jurnal Agroland. 16 (1) : 53 - 59.

Basrowi. 2011. Kewirausahaan Untuk Perguruan Tinggi. Jakarta: Ghalia Indonesia.

Dhamayantie, Endang, Fauzan R. (2017). Penguatan Karakteristik Dan Kompetensi Kewirausahaan Untuk Meningkatkan Kinerja UMKM. Matrik: Jurnal Manajemen, Strategi Bisnis dan Kewirausahaan.11(1):53-59 DOI: https://doi.org/10.24843/MATRIK:JMBK.2017.v11.i01.p07 .

Djuwendah, Endah. (2019). Penguatan Kelembagaan Koperasi Produsen Kopi Java Preanger Dalam Upaya Meningkatkan Kinerja Bisnis Dan Pendapatan Petani Kopi. Dharmakarya.7(4); 228 - $23 . \quad$ DOI : https:// doi.org/ 10.24198/dharmakarya.v7i4.9773.

Jumaedi H. 2012. Hubungan Karakteristik Wirausaha Terhadap Keberhasilan Usaha (Studi Kasus pada Pengusaha Kecil di Pekalongan). Vol. 11, No. 21.

Isa, Muzakar, (2011). Analisis Kompetensi Kewirausahaan, Orientasi Kewirausahaan, dan Kinerja Industri Mebel. BENEFIT Jurnal Manajemen dan Bisnis. 17(1):89-98.

Martauli ED, Siahaan LM. (2019). Pengaruh Karakteristik Wirausaha Terhadap Kinerja Usahatani Kopi Arabika di Kabupaten Karo. Journal of Agribusiness Sciences 3(1): 16-23.

Pambudy R, Priatna WB, Burhanuddin. 2017. Kewirausahaan Dan Manajemen Bisnis Kecil.Bogor: Idemedia Pustaka Utama. 
Purwaningsih, R. and Kusuma Damar, P. (2015). Analisis Faktor-Faktor Yang Mempengaruhi Kinerja Usaha Kecil Dan Menengah (Ukm) Dengan Metode Structural Equation ModelinG (Studi kasus UKM berbasis Industri Kreatif Kota Semarang)', E-Journal Undip.

Sari, N. M. W., Suwarsinah, H. K. and Baga, L. M. (2016) 'Pengaruh Karakteristik Kewirausahaan terhadap Kinerja Usaha Mikro, Kecil dan Menengah(UMKM) Gula Aren di Kabupaten Lombok Barat. Jurnal Penyuluhan. doi: 10.25015/penyuluhan.v12i1.11320.

Setyawati, H. A. (2013). Pengaruh Orientasi Kewirausahaan dan Orientasi Pasar terhadap Kinerja Perusahaan melalui Keunggulan Bersaing dan Persepsi Ketidakpastian Lingkungan sebagai Prediksi Variabel Moderasi (Survey pada UMKM Perdagangan di Kabupaten Kebumen)', Jurnal Fokus Bisnis. doi: 10.1017/CBO9781107415324.004.

Sirappa, I. P., Sunarso, S. and Sumekar, W. (2017). Faktor-Faktor Yang Mempengaruhi Curahan Tenaga Kerja Keluarga Dalam Pengembangan Ekonomi Usaha Sapi Perah Di Kecamatan Ungaran Barat, Kabupaten Semarang. Agrisocionomics: Jurnal Sosial Ekonomi Pertanian. doi: 10.14710/agrisocionomics.v1i1.1646.

Sugiyono. (2017). Metode Penelitian Kuantitatif, Kualitatif dan R\&D. Bandung: PT Alfabet.', Sugiyono. (doi: 10.1017/CBO9781107415324.004.

Wahyuningsih DC. (2015). Pengaruh Perilaku Kewirausahaan Terhadap Kinerja Usaha Industri Bawang Goreng Di Kota Palu Provinsi Sulawesi Tengah. [skripsi]. Institut Pertanian Bogor. 